\title{
Empowering and disempowering students in student- supervisor relationships
}

Author:
Salome Schulze ${ }^{1}$
Affiliation:
${ }^{1}$ Department of Further
Teacher Education, University
of South Africa, South Africa
Correspondence to:
Salome Schulze
Email:
schuls@unisa.ac.za
Postal address:
PO Box 392, Pretoria 0003 ,
South Africa
Dates:
Received: 31 Oct. 2011
Accepted: 13 June 2012
Published: 13 Dec. 2012
How to cite this article:
Schulze, S., 2012,
'Empowering and
disempowering students
in student-supervisor
relationships', Koers -
Bulletin for Christian
Scholarship 77(2), Art. \#47,
org/10.4102/koers.v77i2.47

(C) 2012. The Authors. Licensee: AOSIS OpenJournals. This work is licensed under the Creative Commons Attribution License.
In South Africa, the issue of empowerment or disempowerment in student-supervisor relationships has not been adequately addressed. Research for this article therefore aimed at determining how students are empowered or disempowered in their relationships with their supervisors. The conceptual framework for the research comprised social constructivism, critical pedagogy and theory on the empowerment of students. In the phenomenological case study, 15 master's and doctoral students with 9 different supervisors from one college at the University of South Africa, and who had recently graduated, were purposefully selected for interviews. The findings of the study revealed that the students were not always empowered through sustained two-way communication in a supportive environment. In order to empower students, supervisory styles need to change from power-centred to facilitationcentred supervision. The study also showed that many supervisors found it difficult to adopt this style in a distance-education environment. The study is significant for generating a model that illustrates the interaction between various forces related to supervisory practices. Some recommendations for improvement were made.

Bemagtiging en ontmagtiging van studente in die verhouding tussen student en studieleier. Die kwessie van bemagtiging in die verhouding tussen student en studieleier is nog nie in Suid-Afrika deeglik ondersoek nie. Die studie waaroor hierdie artikel handel is dus daarop gemik om te bepaal hoe studente in hul verhoudings met hul studieleiers bemagtig of ontmagtig word. Die teoretiese raamwerk van die studie was sosiale konstruktivisme, kritiese pedagogie en teorieë oor die bemagtiging van studente. 'n Fenomenologiese gevallestudie-navorsingsontwerp is gebruik. Vyftien meesters- en doktorale studente met nege verskillende studieleiers van een kollege aan die Universiteit van Suid-Afrika, en wat onlangs gegradueer het, is doelgerig vir onderhoude geselekteer. Die bevindinge van die studie toon aan dat studente nie altyd deur volgehoue, tweerigting-kommunikasie in 'n ondersteunende omgewing bemagtig is nie. Om studente te bemagtig, moet supervisiestyle van maggesentreerde na fasiliterende supervisie verander. Die studie het ook aangetoon dat baie studieleiers dit moeilik gevind het om hierdie styl in 'n afstandsonderrigkonteks te aanvaar. Die studie is belangrik omdat dit ' $n$ model genereer wat die interaksie van verskeie invloede op die supervisieverhouding illustreer. Aanbevelings vir verbetering is ook gemaak.

\section{Introduction}

For South Africa to flourish, it is essential to create a highly skilled workforce that can compete in a complex world. One way to create such a workforce is through the delivery of quality research students. However, a large proportion of South African doctoral students do not complete their studies (Metcalfe 2011:1). It has also been pointed out that insufficient numbers of Black and women graduate students obtain doctoral degrees (Dietz et al. 2006:3). This issue points to the need for an in-depth examination of the processes by which students learn about research and the methods supervisors use to facilitate the process, as also noted by Zuber-Skerritt and Roche (2004:83). Both the processes and the methods used are determined by supervisory styles. Armitage (2007) identified these styles as power-centred or facilitation-centred, whilst Rau (2008) coined them as push or pull (power-centred) or allow (facilitation-centred).

The student-supervisor relationship can never be completely free of power dimensions (Cadman \& Ha 2001:217). Power in itself is not a bad thing. Supervisors' use of power is positive if it promotes an atmosphere of safety and if supervisors collaborate with students and consciously empower them. As consumers, students also have power which can be strengthened through peer solidarity (Murphy \& Wright 2005:283).

Examples of the negative use of power are when supervisors enforce specific orientations onto a study or violate confidentiality (Murphy \& Wright 2005:283). If supervisors use the traditional 
model of supervision, which is based on behaviourist theories of learning, this disempowers students because it tends to focus only on the technical aspects of the research and the thesis production and not on how the students are shaped (Cadman \& Ha 2001:217; Zuber-Skerritt \& Roche 2004:88).

Quan-Baffour and Vambe (2008), referring to supervision in distanceeducation(DE) in particular, recommended 'dynamic facilitation' in a supportive environment, based on social constructivist theories of learning. Coined a 'cooperative model of interaction' (Bartlett \& Mercer 2000:199), this highlights the role of high-quality conversation between supervisors and students. Unfortunately, many supervisors seem disinterested in actively engaging with students (Heydenrych 2009:5, 25), which could be disempowering.

Bartlett and Mercer (2000:195) confirmed that supervision was often complicated by power issues that supervisors and students were reluctant to talk about. In the South African context in particular, power-related issues in studentsupervisor relationships have not been investigated in depth (Rau 2008:1). This is also evident from the five hits that an electronic search found. Not one of these studies was conducted in a DE context. DE institutions face specific challenges to provide empowering supervision because of the generally limited personal contact between supervisors and students.

The study on which this article is based therefore aimed at answering the following research question: How are postgraduate students at one college at the University of South Africa (UNISA) empowered or disempowered in their relationships with their supervisors?

The investigation was framed by constructivist theories of learning and by critical theory, which are briefly explained. Power dynamics in the supervisory relationship are thereafter reviewed.

\section{Conceptual framework Constructivist learning theories}

The worldview that was used as foundation for this article can best be identified as postmodern. Postmodernism has as its main characteristic the rejection of absolute truth. This is in line with the following transformative and social constructionist perspectives: knowledge is changeable, there is no objective knowledge and truth is relative to a particular frame of reference, such as culture or worldview (Van den Berg 2011:6). This viewpoint is criticised by some Christian scholars. For instance, Henze $(2008: 103,108)$ states that the Christian believes that there are objective truths that have been revealed in the Bible. To yield truth, a constructivist pedagogy should be constructed with a Christian foundation. However, the number of Christian scholars who support postmodern thinking (including the author of this article), indicates that this debate is not over (Christian Colligation of Apologetics Debate Research \& Evangelism n.d.).
Social constructivist approaches are relevant to this research and highly recommended for supervision by authors such as Quan-Baffour and Vambe (2008), as mentioned. Social constructivists emphasise the social contexts of learning and that knowledge is mutually built and constructed (Santrock 2008:337-361). Scaffolding relates to changing the level of support from direct instruction to guidance over the course of a learning programme. An important tool is cognitive apprenticeship, during which experts, such as supervisors, stretch and support the students' understanding and use of relevant skills. During cooperative learning, students in groups help each other to learn.

A socio-constructivist approach enables one to see students as capable of critically questioning dominant beliefs and focuses on students' empowerment. The enhancement of critical thinking can be linked with Foucault's beliefs. Critical thinking can reveal injustices and inequities in current beliefs and practices. It can also overcome the limitations of cultural conditioning (Heydenrych 2009:33). According to this line of thinking, the task of supervisors is 'to encourage learners to become critical and creative thinkers on their path to selfdiscovery and empowerment' (Van den Berg 2011:11).

\section{Power dynamics in supervisory relationships}

There are various definitions of power. Two examples are: 'Power is the existence of inequalities' (Stack in Rau 2008:6), and 'The power of an individual or institution is the ability to achieve something, whether by right or by control or influence' (Oxford Dictionary of Philosophy 2012:4).

Some characteristics of power and power tactics include that power can be intentional or there may be no knowledge or awareness of it. Power can also constrain or enable human action. Power tactics that people use to prompt others into a particular action can be harsh and forceful, or more indirect (hard or soft tactics). Some power tactics are enacted by negotiation whilst others are imposed without input from the other party (bilateral or unilateral). Furthermore, tactics can make use of reasoning and logic, or it can rely on emotions and misinformation (rational or non-rational) (Dietz et al. 2006)

According to Foucault (Grant 2001:14), all social relations are systems of power, and all parties in a relationship have some power since each party is capable of acting upon the other. The balance of power can be equal or unequal and constant or subject to transformation. Individuals should be aware of how they are shaped by discourse, should resist being controlled by others and should take responsibility for empowering themselves. When Foucault (1996:441-442) refers to the need to 'produce one's own self', he is pointing to the discovery of personal authenticity.

The social psychologists French and Raven (Schulze 2012) identified six power bases. Applied to postgraduate supervision, these foundations are as follows: 
- positional (legitimate) power is related to the position and duties of a supervisor at a university

- referent power is the ability of a supervisor to attract students and build loyalty based on identification and respect

- expert power is derived from the skills and expertise of the supervisor and the university's need for this expertise

- reward power is the ability to give a reward of some kind, for example, by commenting positively on students' work

- coercive power is the ability to demote or withhold rewards, and it can build resentment, for example, students may obey supervisors for fear of recrimination

- informational power is when supervisors give or withhold valuable information from students (e.g. related to bursary applications)

According to Conti, Hewson and Isken (2001:165), a solid student-supervisor relationship is based on each party earning legitimate, referent and expert power in the eyes of the other.

Supervisors and students have to share power to create and recreate knowledge through negotiation and communication (Brew 2006:32). Generally, power dynamics in the studentsupervisor relationship vary over the course of a study as the student becomes more knowledgeable and gains control over the study (Kelly \& Ling 2001:74). According to Conti et al. (2001):

In particular, students need legitimate power, that is, the right to claim their voice, be an active agent in their supervision, and have responsibility and ownership of the process and product. (p. 166)

This statement is also in accordance with critical theory as shown in the previous section.

Addressing the power inherent in different supervisor styles, Armitage (2007:26) identified a continuum with power-centred supervision (directive and task-oriented) at the one end and facilitation-centred supervision (nondirective and processoriented) at the other end. Supervisors with different styles vary with regard to how they handle problem identification and solving, feedback and support given to the students, how they function as subject experts or as authority figures and how they evaluate and respond to the students' work.

With the preceding sections as background, this research aimed at determining how students were empowered or disempowered in their relationships with their supervisors. To this end, the remainder of the article explains the research design, data collection, findings (integrated with a literature control) and conclusions of the study.

\section{Research method}

The study aimed at gaining an in-depth understanding of power relations in the student-supervisor relationship in one college at UNISA. The research design was a phenomenological case study.
Maximum variation sampling ensured that a variety of perceptions about supervision amongst information-rich participants could be obtained (McMillan \& Schumacher 2010:326, 490). Fifteen master's and doctoral students, who had just graduated, were selected. (Students who were not successful could be the focus of a follow-up investigation.) Some of the students were selected from graduation programmes, and others were chosen through snowball sampling. The students were from different cultural and gender groups. Nine students had successfully completed their master's dissertation, and six had completed their doctoral thesis. The supervisors and promoters (referred to as 'supervisors' in this article) were White males and White females, with one exception (a Black male). Supervision thus crossed gender and cultural boundaries. One supervisor supervised two of the students, and another supervisor supervised three. For practical reasons, all the students who were selected lived within $100 \mathrm{~km}$ of the University of South Africa (UNISA). The students could therefore occasionally meet with their supervisors, although in general the supervision was conducted at a distance.

The duration of each interview was about one hour. Amongst others, the students were requested to describe their relationships with their supervisors and to comment on their supervisors' styles of supervision. Probing questions were asked, such as requesting respondents to provide examples.

The answers were analysed by means of the constant comparative method. Categories were formed through a recursive process which involved 'the repeated application of a category to fit codes and data segments' (McMillan \& Schumacher 2010:377).

Ethical measures that were taken included informed consent, assurances of anonymity and confidentiality and consent to use a tape recorder. The validity of the design was enhanced by means of the following strategies (McMillan \& Schumacher 2010:330-332). The interviews were in a language that the participants could understand. The sampling decisions were made carefully. The interviews were recorded, and verbatim transcriptions were made. The findings of the study are explained in the next section.

\section{Findings and discussion}

The main categories that were identified in the study are communication, support, feedback, and critical discourse, self-reflection and creative thinking. Quotes are by Black males (BM), Black females (BF), White males (WM) and White females (WF).

\section{Communication}

Stimulating conversations in the co-construction of knowledge lead students to find their own voice when writing their dissertations (Leonardo 2004:11). In the study, communication often took the form of faceless encounters 
via telephone, cell phone and email. All the students had the contact details of their supervisors at hand. However, two-way communication could obviously not be sustained if supervisors were 'remote' or difficult to contact. This had a particularly disempowering effect on students with a low research self-efficacy (SE) who doubted their own abilities. For example, referring to informational power, a student said:

'My one friend said that when he did his MEd over a long time period, he nearly changed supervisors because he said the guy was impossible; he was always out. But Prof X [the supervisor] did this: if he knew he would be out for a long time, he would inform me and tell me that he would not be available at the office for the following three weeks. That assisted me a lot.' (BM, 55 years old, Secondary School headmaster)

Some supervisors initiated contact with students even though Mouton (2001:22) sees this as the responsibility of the student. One student with a facilitation-centred supervisor who provided pastoral care stated:

'There were times when I had momentum and things went well, but there were times when nothing happened. What helped me in both instances was regular contact. We both initiated this. It put a moral obligation on me to try to put something on the table ... even if it was just a paragraph.' (WF, 44 years old, Trainer of adults)

\section{Support}

The most empowering or disempowering aspect of supervision related to the nature of the support that supervisors provided. A collaborative partnership where a supervisor focused on the process of supervision rather than the product was particularly important for master's students and for those with low research SE.

Mouton (2001:20) points out that top scholars were often over-committed and did not have enough time for quality supervision. In one example, a master's student got the subtle message that her supervisor was a busy professional with many other responsibilities and that her time needed to be respected. This facilitated feelings of alienation - as was also found by Cadman and Ha (2001:227). However, she was afraid to take a standpoint on the issue, for fear of recrimination.

\section{Hierarchical relations}

Kelly and Ling $(2001: 74,75)$ viewed the success of the studentsupervisor relationship as depending on 'a negotiation of common meanings' and 'a mutual trust and narrative'. Some student-supervisor interactions in the study showed parity in relations and mutuality in meaning making and facilitated reference power in both parties. For example, a White male related how he struggled to find a supervisor who would not be intimidated by his significant knowledge and experience on the topic he wanted to investigate. Eventually someone was appointed who was willing to act as his supervisor and co-learner. He said:
'I always called him "professor", but he said I should call him by his first name. I never experienced him as an elevated figure, so I contacted him whenever I wanted to.' (WF, 50 years old, Trainer of adults)

Other students perceived their supervisors as strict superiors. One male student gave the following example of positional power:

'If you make an appointment with him, make sure that you keep it. If he says nine o'clock and you come at eight o'clock, he's not going to allow you in. He's going to allow you in at nine o'clock. So, he is very strict ... He is firm because if something is wrong, he's not going to take it. He would advise you to do the correct thing.' (BM, 55 years old, Secondary School headmaster)

Reporting an example of coercive power, some students were afraid to complain, for example about long turnaround time, for fear of reproach. This confirmed the findings of Bartlett and Mercer (2001:8).

\section{Roles and responsibilities: Shared control or enforcement}

It was clear from the student interviews that academics' beliefs about their own role and responsibility varied from powercentred to facilitation-centred supervision. Hence students referred to them as 'friends', 'coaches', 'quality controllers,' 'expert guides' and 'mentors'. According to Manathunga (2007:208), 'portraying supervision as mentoring and therefore as innocent, neutral practice serves only to mask the very role ... that power plays within supervision', seeing that paternalistic characteristics remain. Such characteristics include seeing the student as an 'obedient and devoted apprentice' (Manathunga 2007:210).

Since every supervisor and student is different, their relationships are also unique. In the study, the relationships of three students with the same supervisor were diverse and were possibly influenced by the students' differences in abilities, culture and gender. The one doctoral student had a poor educational background and exhibited low research SE which facilitated learned helplessness (Olivier 2007:1129). For Black students, this could be a legacy of the past. Referring to a conversation during which his supervisor urged him to take responsibility for his learning, a male student stated:

'Look I'm a student ... and to me, my definition of a student is somebody who is assisted ... it's a learner. And obviously I'll make mistakes and that is why I have a promoter. His duty is to assist me.' [Interviewee's emphasis] (BM, 55 years old, Secondary School headmaster)

The above need for direct instructions was also found by other authors, for example, with international students in Australia (Cadman \& Ha 2001:224; Dietz et al. 2006:74; Manathunga 2007). It highlighted the dilemmas of supervisor-student pairings in which the individuals were at odds with their preferred supervisory styles (Mainhard et al. 2009:360).

If students had research SE, they could assume responsibility to address challenges with limited support and even benign neglect. In one example, a master's student, who managed to 
obtain her degree with distinction, reported benign neglect as follows:

'She [the supervisor] told me that I started it and had to run with it. So, I had to struggle on my own to keep my head above the water. I am very proud that I managed. Maybe it is her way of encouragement ... not to spoon-feed students. It would have been easier if she had answered my questions, but I had to find out for myself. It was a lonely road.' (WF, 42 years old, Teacher)

There was evidence of shared control, which was empowering, if supervisors were willing to listen to their students' views and discuss or debate differences. Students were empowered by supervisors who challenged them but allowed them to take ownership for determining the direction and tempo of their studies. For example:

'She gave you credit for thinking for yourself. If she saw you were on the right track, she would just let you carry on. She was also open to suggestions ... but she would say: 'You must do this ... you're going too far. Don't go there. You know, things like that.' (WF, 42 years old, Psychologist)

In contrast to the above, some students were coerced into investigating topics that suited the supervisors but did not interest them: 'And then you become more confused because it is not something that you want to work on' (BF, 46 years old, Psychologist).

The student-supervisor relationship was enhanced if the students sensed that their supervisors had genuine interest in their research topics. Some of the students indicated that their supervisors provided them with relevant articles even though it was not their responsibility to do so. Such concrete evidence of interest and support was motivational and therefore empowering and enhanced the supervisor's referent power.

Research design issues were often raised in the interviews. However, there was little evidence of critical discussion and debate on design issues, in line with socio-constructivist learning and facilitation-centred supervision. A (doctoral) student indicated that he believed he got too little support his promoter expected him to make his own research design decisions and did not detect various limitations in the work. Other power-centred supervisors made design decisions on behalf of their students. In one example, a master's student told the interviewer how her supervisor had coerced her 'to go the quantitative route because he was statistically inclined, but I even had to find my own assistance with that' (BF, 41 years old, Lecturer).

\section{Planning the study and setting objectives within time frames}

The study revealed that clear guidelines on writing dissertations empowered students. Mouton (2001:17) regards this type of guidance as the responsibility of supervisors. It includes discussion between the supervisor and student on how to structure the dissertation, what each chapter should entail (e.g. by providing students with examples), and the coherence between the chapters. It also includes editorial requirements such as referencing and the list of references as well as the importance of doing this correctly from the start. Thus, students were empowered by supervisors who helped them to submit their study plans in writing, referred to as the 'architecture' of a study by Trafford and Lesham (2008:53). This planning was enhanced by the use of visual techniques that included diagrammes ('skeletons') and time frames that helped them to envision the way forward. A doctoral student explained:

'This thing of self-doubt is a terrible thing. If you do not know how to do something, it becomes a huge stumbling block. Then you keep postponing, whilst if you know and when it is divided into chewable chunks, you can do each task on time. Then you are not overwhelmed. I could see exactly what I would do but would not have been able to do it without my supervisor's support.' (WF, 62 years old, Lecturer)

\section{Emotional support (pastoral care)}

The human side of supervision is often neglected, particularly in a DE context and if supervisors have a power-centred, businesslike style of supervision (Dietz et al. 2006:71; Mouton 2001:18). Acknowledging the student as a person in addition to as a learner is vital, leads to the notion of 'pastoral care' (Salmon in Symons 2001:105) and earns supervisors referent power. One student who had experienced facilitationcentred supervision related how she wanted to discontinue her studies because she felt discouraged by overwhelming personal circumstances. Her supervisor did not put any pressure on her to continue immediately but advised her to take a break and to keep in touch. He also phoned her from time to time. This enabled her to regain her composure and continue her studies. Another student stated: 'Sometimes she [the supervisor] would write things like: 'Good luck with your work.' It seems like it's a minor thing, but it had an impact' (BF, 44 years old, Nurse).

The emotional stability of supervisors could also impact on relationships. In one example, a master's student's studies were significantly influenced by the personal trauma of her supervisor. She was unable to provide appropriate guidance and the student had to resubmit her dissertation for examination which 'shattered' her self-confidence. After completing her doctoral thesis under the expert guidance of a different supervisor, she went on to become an informal mentor to postgraduate students who were colleagues, 'giving them the guidance I would have wanted when I was a master's student'.

\section{Facilitating exposure}

Supervisors had informational power and could facilitate students' exposure to the academic community. At UNISA, various workshops on research skills for students and staff were continuously being offered by a research directorate. However, not one student in the study indicated that he or she had participated in the workshops.

Some students expressed the wish to attend conferences to present papers or to write articles about their work. At 
conferences, dominant ideologies and stereotypical views were often questioned. Thus, the exposure could empower the students by developing their critical thinking skills. Moreover, some students indicated that participation in conferences and publication enhanced their career opportunities.

\section{Feedback}

All the students pointed out that prompt feedback was pivotal. It empowered students because it enabled them to keep their momentum. The students found long waiting periods frustrating but were afraid to complain.

The interviews revealed how a supervisor differed in her interaction with two of her students. Her one (Black female) master's student considered 'giving up' because of long turnaround times of up to three months. In the absence of effective communication, she concluded that her poor work was causing the delays. However, another (Black female) master's student of the same supervisor expressed her satisfaction with quick feedback. Further probing revealed that her topic was within the supervisor's own research interest and expertise, in contrast with the topic of the first student.

The study also revealed that constructive feedback was needed. Criticism that was presented as guidelines or that was framed as suggestions built confidence. Conscious consideration of how to frame recommendations for change was particularly important for previously disadvantaged students who often had to redo chapters several times. Students were discouraged by harsh criticism, in particular at the start of their studies and if they tended to take the criticism personally, as indicated by one student.

A supervisor's personal revelation of fallibility could build a student's confidence. In one example, a supervisor disclosed that he too had to redo work in study guides or articles in accordance with criticism he received. This was empowering because it enhanced student confidence.

The study further brought to light that both supervisors and students often communicated in their second or third languages, which led to feedback being unclear or misunderstood, as also found by Schulze (2012:46). A Black female said that she understood personal, oral communication. However, when her supervisor communicated with her on paper, she found it difficult to make sense of what he was saying. De Beer and Mason (2009:223) also found that the disadvantages of electronic communication included the fact that there could be misunderstandings, critiques could seem too brusque and could be experienced as personal. McAlpine (2011) therefore emphasised the importance of checking with students their understanding of the feedback they received. The students in this study felt safe if they submitted work electronically but could discuss the assessed work in person (if possible) in addition to receiving written feedback.
Students also felt disempowered by inconsistent feedback. For example:

'The advice that I got, especially when it came to research methods, it kept on changing ... and I got so confused. And after the completion of the whole thing ... the person who did the editing picked up lots of things .... and I wondered how she [the supervisor] was unable to pick that up earlier. It was almost redoing lots of the work.' (BF, 44 years old, Psychologist)

\section{Critical discourse, self-reflection and creative thinking}

Supervisors who were facilitation-centred encouraged an exchange of views and the consideration of multiple perspectives. The study showed that critical discourse generally took place during personal meetings, which only confirmed Van der Linde and Holtzhausen's (2008:107) finding that students desired personal meetings to receive their feedback. This highlighted the dilemma of the DE supervisor. During such meetings, supervisors posed questions such as: 'What about if ...?' or challenged students with contesting viewpoints. This was likely to occur if the supervisor was knowledgeable in the student's study field. For example:

'My supervisor had the ability to challenge me. He did not accept my conclusions. We would always argue over it, and I had to explain how I arrived at the conclusion. He often played devil's advocate. At first, it frustrated me, but I came to realise how valuable it was. He would ask me if I had read the work of $Y$ and if I hadn't, he would request that I read it and then we would discuss it.' (WF, 44 years old, Trainer of adults)

Discussions such as these enabled students to construct knowledge and find their own voice. The students were empowered by supervisors who could reach a compromise with students when they differed on issues. However, debating matters with supervisors was not always easy for Black students who came from cultures where there was a high regard for older people and those in leadership positions. According to Heydenrych (2009:33), supervision that enhances critical thinking can overcome the limitations of cultural conditioning.

\section{A model for supervision}

From the above, it is clear that there is a reciprocal relationship between the personal characteristics and the behaviour of both the student and the supervisor in the relevant context, for example, a DE environment. This relationship is dynamic and can change over the period of the study. Diagrammatically, this can be depicted as follows.

In Figure 1, the personal characteristics of the students include their abilities (such as language ability), previous knowledge and experience, cultural beliefs, beliefs about the role and responsibilities of supervisors and students, and research SE. The personal characteristics of the supervisor include knowledge and experience in research and supervision in particular and beliefs about the role and responsibilities of supervisors and students. These beliefs determine their 


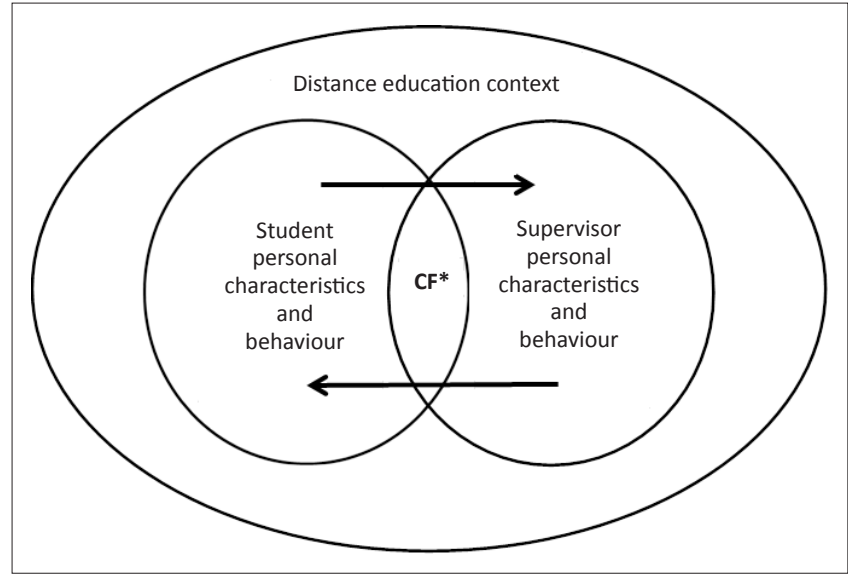

$\mathrm{CF}^{*}$, Conceptial framework.

FIGURE 1: A model for supervision.

supervisory style as power-centred or facilitation-centred. This is in line with postmodern thinking that truth is relative to participants' frame of reference.

The study revealed that although students are empowered by sustained two-way communication in a supportive environment, this is not easily accomplished in a DE context. A supportive environment is characterised by respect and equality in relations, shared autonomy, assistance with the structure and scholarship of the dissertation (ensuring that it meets the assessment criteria of the institution), pastoral care, the facilitation of interaction with peers and exposure to conferences and publication. Quick feedback of a high quality is crucial.

The study also revealed that many supervisors find it challenging to stimulate students' critical thinking skills in a DE context. The supervisors who consciously stimulated reflection and critical thinking skills in their students, through techniques that included questioning, commenting and suggesting alternatives, tended to be the supervisors who personally met with their students. Students should find their own voice and take ownership of their projects. This leads to legitimate power and self-transformation. To overcome cultural beliefs that may inhibit this kind of dialogue, upfront communication about expectations (initiated by supervisors at the start of the students' studies) is required.

\section{Conclusion and recommendations}

In line with post-modern thinking that rejects absolute truths, the aim of this study was not to generalise or determine causality. Rather, the aim was to gain an indepth understanding of empowering and disempowering supervisory practices in one college at UNISA as a DE institution at the time of writing. In this research, the focus was limited to the perceptions of the students. Determining the views of supervisors on issues of power could be the focus of a following project.

The study pinpointed the role of the supervisor as pivotal in enabling or constraining students. The most important finding was that there was a need to change dated, powercentred ways of providing supervision. Supervisors have to actively engage in their relationships with their students in order to help them to find their own voice. This requires time and effort and highlights the importance of greater consideration of the overall workload of supervisors. The active recruitment of experienced, recently retired professors to assist with postgraduate supervision could be considered.

In the study, some students revealed that they had felt neglected and had been given too little academic or emotional support when they needed it. Apart from workload, this may be attributed to different beliefs amongst supervisors regarding their own responsibilities versus those of their students. More institutional discourse is needed to facilitate reflection on supervisory practices so that supervisors can identify their own styles and the implications for learning. Supervisors also need to reflect on relevant learning theories as outlined in the conceptual framework.

In addition to the above, the study revealed some tension regarding best supervisory practice. For example, facilitative supervision regards students as equals and encourages active participation in discourse around research issues. However, some students with low research SE adopted a passive role and expected direct instructions from their supervisors. Admission requirements that allowed students of poor academic ability into the system need to be reconsidered. Although a mark of at least $60 \%$ at honours level is currently required for admission to master's studies at UNISA, students require different cognitive skills for postgraduate research than for coursework examinations. Moreover, roles and responsibilities should be openly discussed and negotiated between supervisor and student at the start of the research.

The study determined that there were supervisors who coerced their students into investigating research topics or using designs of the supervisor's choice. Such unilateral decision making within power-centred supervision constrained students. At the same time, it pointed to flawed practices in how supervisors were appointed. This issue needs to be addressed.

Students who were unhappy in their relationships with their supervisors, sometimes for legitimate reasons, felt powerless to address the problem. Some kind of feedback to chairpersons of departments or directors regarding supervisory practices could be considered. Students could also be provided with information on suitable steps to take to address relationship difficulties.

Apart from differences in expectations (regarding roles and responsibilities) and abilities (including language abilities) of both students and supervisors, a key factor that emerged was the involvement (interaction and communication) of the supervisor. Each student-supervisor relationship was distinctive and enabled or constrained the student. What was needed as the basis for postgraduate pedagogy in some cases was greater 'connection' between supervisor and student. To 
this end, supervisors and students should share experiences, perspectives and decision-making tasks. As mentioned, the practicalities of how this can be done more effectively than is presently happening within a DE environment need further investigation. The role of technology, such as Skype, could be explored as it gives supervisors and students the opportunity for personal, real-time communication.

Although postgraduate pedagogy is enjoyable, it is also difficult. More academic discourse on the various issues that this article raised is needed. A healthy, power-balanced supervision relationship can improve the quality of theses or dissertations and, by implication, the quality of graduates.

\section{Acknowledgements Competing interests}

The author declares that she has no financial or personal relationships which may have inappropriately influenced her in writing this article.

\section{References}

Armitage, A., 2007, 'Supervisory power and postgraduate supervision', Internationa Journal of Management Education 6(2), 18-29. http://dx.doi.org/10.3794/ ijme.62.179

Bartlett, A. \& Mercer, G., 2000, 'Reconceptualising discourses of power in postgraduate pedagogies', Teaching in Higher Education 5(2), 195-204. http:// dx.doi.org/10.1080/135625100114849

Bartlett, A. \& Mercer, G., 2001, 'Mostly metaphors: Theorizing from a practice of supervision', in A. Bartlett \& G. Mercer (eds.), Postgraduate research supervision - Transforming (r)elations, pp. 55-70, Peter Lang, New York.

Brew, A., 2006, Research and teaching: Beyond the divide, Palgrave Macmillan, Basingstoke.

Cadman, K. \& Ha, H.T., 2001, "'Only connect": Transactional supervision as the "rainbow bridge"', in A. Bartlett \& G. Mercer (eds.), Postgraduate research supervision: Transforming (r)elations, pp. 215-232, Peter Lang, New York.

Christian Colligation of Apologetics Debate Research \& Evangelism, n.d., Christianity and postmodernism, viewed 31 January 2012, from http://christiancadre.org/ topics/postmodern.html

Conti, J., Hewson, D. \& Isken, J., 2001, 'Power, voice and connection', in A. Bartlett \& G. Mercer (eds.), Postgraduate research supervision - Transforming (r)elations, pp. 161-174, Peter Lang, New York.

De Beer, M. \& Mason, R.B., 2009, 'Using a blended approach to facilitate postgraduate supervision', Innovations in Education and Teaching International 46(2), 213-226. $\mathrm{http}: / / \mathrm{dx}$.doi.org/10.1080/14703290902843984

Dietz, A.J., Jansen, J.D. \& Wadee, A.A., 2006, Effective PhD supervision and mentorship, Rozenberg, Amsterdam.

Foucault, M., 1996, Foucault live: Collected interviews, 1961-1984, Semiotext, New York.
Grant, B., 2001, 'Dirty work: "A code for supervision": Read against the grain', in A. Bartlett \& G. Mercer (eds.), Postgraduate research supervision - Transforming (r)elations, pp. 13-24, Peter Lang, New York.

Henze, M.E., 2008, 'Demystifying "constructivism": Teaching unnecessary baggage from useful pedagogy', Christian Education Journal 6(1), 87-111.

Heydenrych, J.F., 2009, 'The effect of organizational culture, discourse and occupational identity on engagement in distance delivery', Progressio 31(1/2), 17-37.

Kelly, R. \& Ling, L., 2001, 'A posttraditional supervisor-supervisee relationship', in A. Bartlett \& G. Mercer (eds.), Postgraduate research supervision - Transforming (r)elations, pp. 71-78, Peter Lang, New York.

Leonardo, Z., 2004, 'Critical social theory and transformative knowledge: The functions of criticism in quality education', Educational Researcher 33(6), 11-18. http://dx.doi.org/10.3102/0013189X033006011

Mainhard, T., Van der Rijst, R., Van Tartwijk, J. \& Wubbels, T., 2009, 'A model for the supervisor - doctoral student relationship', Higher Education 58, 359-373. http:// dx.doi.org/10.1007/s10734-009-9199-8

Manathunga, C., 2007, 'Supervision as mentoring: The role of power and boundary crossing', Studies in Continuing Education 29(2), 207-221. http://dx.doi. org/10.1080/01580370701424650

McAlpine, L., 2011, 'Making sense of supervision: Student perspectives on the doctoral journey', paper presented at the Third Biennial Conference on Postgraduate Supervision, Stellenbosch, 18-21 April.

McMillan, J.H. \& Schumacher, S., 2010, Research in education - Evidence-based inquiry, 7 th edn., Pearson, Boston.

Metcalfe, M., 2011, Effective PhD supervision - Chapter one: Introduction, viewed 01 February 2012, from http://rozenburgquarterly.com/p=1854

Mouton, J., 2001, How to succeed in your master's \& doctoral studies - A South African guide and resource book, Van Schaik, Pretoria.

Murphy, M.J. \& Wright, D.W., 2005, 'Supervisees' perspectives of power use in supervision', Journal of Marital and Family Therapy 31(3), 283-295. http://dx.doi. org/10.1111/j.1752-0606.2005.tb01569.x

Olivier, M.A.J., 2007, 'Postgraduate supervision: For better or for worse?', South African Journal of Higher Education 21(8), 1126-1140.

Oxford Dictionary of Philosophy, 2012, viewed 03 February 2012, from http://www. answers.com/topic/power-sociology

Quan-Baffour, K.P. \& Vambe, M.T., 2008, 'Critical issues in the supervision of postgraduate dissertations in distance education environments', Open Education 4(1), $1-10$.

Rau, A., 2008, 'Anarchic educational leadership: An alternative approach to postgraduate supervision,' The Indo-pacific Journal of Phenomenology 8, 1-17.

Santrock, J.W., 2008, Educational psychology, 3rd edn., McGraw-Hill, Boston.

Schulze, S., 2012, 'Students' reflections on postgraduate research', Progressio 34(1), 41-55.

Symons, M., 2001, 'Learning assistance: Enhancing the Ph.D. experience', in A. Bartlett \& G. Mercer (eds.), Postgraduate research supervision - Transforming (r) elations, pp. 101-112, Peter Lang, New York.

Trafford, V. \& Lesham, S., 2008, Stepping stones to achieving your doctorate by focusing on your viva from the start, Open University Press, New York.

Van den Berg, M.E.S., 2011, 'Conceptual foundations for critical reasoning and learner engagement in ODL', Progressio 33(1), 63-79.

Van der Linde, A.S. \& Holtzhausen, S.M., 2008, 'An improvement-oriented investigation into supervision practices at the Central University of Technology, Free State: A case study', Journal for New Generation Sciences 6(2), 97-116.

Zuber-Skerritt, O. \& Roche, V., 2004, 'A constructivist model for evaluating postgraduate supervision: A case study', Quality Assurance in Education 12(2), 82-93. http://dx.doi.org/10.1108/09684880410536459 